\title{
David Oliver: The pundits who do doctors down
}

\author{
David Oliver, consultant in geriatrics and acute general medicine
}

Berkshire

Rigorous, lengthy medical training is a good thing. High levels of public trust in doctors don't result from qualifications obtained like lottery tickets. ${ }^{1}$ Yet a select right wing commentariat with no credible background in healthcare argues that medics are overqualified, overpaid, or operating a cartel to increase income and status.

The Times newspaper quoted UK taxpayer costs of $£ 560000$ ( $€ 735000 ; \$ 820000)$ to train a consultant, conveniently forgetting the decade spent in paid employment, delivering clinical services night and day while studying for exams in "spare time."

Henry Hill, of the Conservative Home blog, proposed an "army of volunteer NHS reservists," ready to step in at a moment's notice." Are emergency physicians or trauma surgeons sitting at home, waiting for the call? We have big workforce gaps, remember?

Sam Bowman, of the libertarian Adam Smith Institute, enjoyed trolling doctors, whom he described on Twitter as "low-tech prescription writing machines" who should "get a real job." 34 Anaesthetists who run intensive care and enable modern surgery are not proper doctors but are more like coffee "baristas," he opined. ${ }^{5} \mathrm{He}$ 's also argued that doctors are overpaid and that entry requirements to medicine should be lowered to flood the labour market. ${ }^{6}$

The pro-market think tank Reform said that about half of GP appointments could be taken by other members of staff or dealt with online-hardly original thinking. ${ }^{7}$ GPs' own organisations have willingly reached this conclusion for themselves already. ${ }^{8}$

The Daily Telegraph executive political editor, James Kirkup, wrote that wearable health monitors, smartphone apps, and surgical robots could make doctors as redundant as British coal miners in a generation, asserting that $85 \%$ of doctors' jobs could be done just as well by less trained and far cheaper staff. ${ }^{910}$

This magical tank-thinking is driven by an ideological animus against public sector professions. It also justifies the think tanks' existence.

But robust empirical evidence that any of this will replace all need for skilled medical care is lacking. UK medical leaders have acknowledged repeatedly that we need to focus more on prevention and self care; they don't need persuading. Short staffed doctors are grateful for any help they can get. A recent Nuffield Trust report, ${ }^{11}$ proposing greater use of advanced practitioner nurses and allied professionals, was welcomed in principle but was misrepresented by the Times. ${ }^{12}$ The NHS already relies extensively on them. But they too face major workforce crises that pundits have ignored in their enthusiasm. ${ }^{13}$ Health services that make more use of markets and competition have higher costs and more doctors. Given a choice, patients tend to pick and choose doctors more, with a penchant for specialists. Back to the drawing board, boys; and Sam, if you ever need surgery, I'd suggest an anaesthetic, not a cappuccino.

Competing interests: See www.bmj.com/about-bmj/freelancecontributors/david-oliver.

Provenance and peer review: Commissioned; not externally peer reviewed.

Page B. Junior doctors' dispute: a pollster's view. BMJ2016;352:11717.

2 Hill H. How the government can defeat the BMA. Conservative Home 2016 Mar 25. www. conservativehome.com/thetorydiary/2016/03/how-a-government-can-beat-the-bma.html.

Bowman S. Tweet, 6 Mar 2016. https://mobile.twitter.com/s8mb/status/ 706452191767355392.

4 Bowman S. Tweet, 6 Mar 2016. https://mobile.twitter.com/s8mb/status/ 706468439129530368.

5 Bowman S. Tweet, 6 Mar 2016. https://mobile.twitter.com/WelshGasDoc/status/ $706518453126111232 ? \mathrm{p}=\mathrm{v}$.

6 Bowman S. The strike is all about money-so why do doctors think they are above criticism? International Business Times $2016 \mathrm{Mar} 11$. www.ibtimes.co.uk/strike-all-aboutmoney-so-why-do-doctors-think-they-are-above-criticism-1548950.

7 Reform. Who cares? The future of general practice. Apr 2016. www.reform. uk/publication/ who-cares-the-future-of-general-practice/.

8 New NHS Alliance. Reducing avoidable demand for GP appointments: an audit. 2015. www.nhsalliance.org/making-time-in-general-practice/part-1-reducing-avoidable-demandfor-gp-appointments-an-audit/.

9 Kirkup J. Doctors are repeating the mistakes of the miners' strike. Telegraph $2016 \mathrm{Mar}$ 25. www.telegraph.co.uk/news/2016/03/25/doctors-are-repeating-the-mistakes-of-theminers-strike/.

10 Kirkup J. Strike all you like, doctors-technology will soon take away your power. Telegraph 2016 Jan 12. www.telegraph.co.uk/news/nhs/12093232/Strike-all-you-like-doctorstechnology-will-soon-take-away-your-power.html.

11 Imison C, Castle-Clarke S, Watson R. Nuffield Trust. Reshaping the workforce to deliver the care patients need. May 2016. www.nuffieldtrust.org.uk/node/4651.

12 Smyth C. Nurses will be trained to cover junior doctors' jobs. Times 2016 May 17. www. thetimes.co.uk/article/nurses-will-be-trained-to-cover-junior-doctors-jobs-szfOnfv8s.

13 Campbell D. The NHS has 70000 fewer staff, new figures reveal. Observer 2016 Apr 3. www.theguardian.com/society/2016/apr/02/nhs-staffing-crisis-70000-go-missing. 
Published by the BMJ Publishing Group Limited. For permission to use (where not already granted under a licence) please go to http://group.bmj.com/group/rights-licensing/

permissions 